\title{
Penerapan Pembelajaran Konstruktivisme dengan Siklus Belajar Karplus untuk Meningkatkan Hasil Belajar Fisika Siswa Kelas VIIb 3 SMP Negeri 14 Palu
}

\author{
I Putu Widi Adnyana1, I Wayan Darmadi², Darsikin³
}

Email: darmadifis@yahoo.co.id

Program Studi Pendidikan Fisika, Jurusan Pendidikan MIPA, Universitas Tadulako

Jl. Soekarno Hatta KM. 9 Kampus Bumi Tadulako Tondo Palu - Sulawesi Tengah

\begin{abstract}
Abstrak - Penelitian tindakan kelas ini bertujuan untuk meningkatkan hasil belajar fisika siswa kelas VIIb 3 SMP Negeri 14 Palu. Masalah yang diteliti adalah rendahnya hasil belajar siswa pada mata pelajaran IPA Fisika. Alternatif pemecahan masalah adalah menerapkan pembelajaran Konstruktivisme dengan siklus belajar Karplus. Subyek penelitian adalah siswa kelas VIIb 3 SMP Negeri 14 Palu, dengan jumlah siswa 34 orang. Penelitian ini dilaksanakan dalam dua siklus dengan materi pokok zat dan perubahannya, masing-masing siklus meliputi 4 tahap: (i) perencanaan (ii) pelaksanaan tindakan (iii) observasi (iv) refleksi. Penerapan pembelajaran Konstruktivisme dengan siklus belajar Karplus dapat meningkatkan hasil belajar fisika siswa kelas $\mathrm{VIIb}_{3}$. Hal ini dapat dilihat pada peningkatan hasil belajar siswa dari siklus I ke siklus II. Untuk hasil belajar siklus I diperoleh nilai ketuntasan belajar klasikal sebesar 50,00\% dan daya serap klasikal 71,18\%. Sedangkan pada siklus II diperoleh nilai ketuntasan belajar klasikal sebesar 82,35\% dan daya serap klasikal 84,51\% yang artinya sudah melebihi standar ketuntasan belajar siswa, peningkatan daya serap klasikal dari siklus I ke siklus II sebesar 13,33\% dan ketuntasan belajar klasikal dari siklus I ke siklus II sebesar 32,35\%. Untuk hasil observasi aktivitas siswa dan guru pada siklus I yaitu cukup dan baik, sedangkan pada siklus II berada pada kategori baik dan sangat baik.
\end{abstract}

Kata Kunci: Pembelajaran Konstruktivisme, Siklus Belajar Karplus, Hasil Belajar Fisika.

\section{PENDAHULUAN}

Pendidikan merupakan salah satu usaha yang dapat dilakukan untuk menyiapkan siswa menghadapi masa yang akan datang. Pendidikan berperan penting dalam mempersiapkan siswa menghadapi berbagai tantangan hidup di masa yang akan datang. Dalam proses pembelajaran masih sering ditemui adanya kecenderungan meminimalkan keterlibatan siswa. Dominasi guru dalam proses pembelajaran menyebabkan kecenderungan siswa lebih bersifat pasif sehingga mereka lebih banyak menunggu sajian guru daripada mencari dan menemukan sendiri pengetahuan, keterampilan atau sikap yang mereka butuhkan.

Berdasarkan hasil observasi awal yang dilakukan di SMP Negeri 14 Palu diperoleh informasi bahwa hasil belajar fisika siswa masih terbilang rendah. Guru sudah melakukan beberapa metode pembelajaran diantaranya adalah metode penugasan baik di dalam kelas maupun di rumah, ceramah serta remedial bagi siswa yang belum tuntas. Tetapi metode ini belum efektif, dikarenakan selama proses pembelajaran berlangsung, siswa cenderung pasif dan sulit memahami materi yang diberikan oleh guru terutama dalam hal ini adalah materi fisika yang identik dengan rumus dan angka-angka. Sehingga mengakibatkan minimnya kemampuan siswa untuk mengeluarkan pendapat dan minimnya pemahaman siswa terhadap materi fisika yang diberikan. Hal ini, berdampak pada hasil belajar siswa yang masih rendah.

Berdasarkan data dan informasi yang diperoleh dari guru mata pelajaran fisika kelas VII bahwa kelas yang memperoleh nilai ratarata hasil belajar fisika pada tengah semester ganjil tahun 2012/2013 yang masih di bawah standar ketuntasan minimum salah satunya adalah kelas VIIb3. Jika dilihat perbandingan persentase ketuntasan siswa di kelas tersebut masih tergolong rendah. Untuk mengatasi kesulitan belajar siswa seorang guru dituntut untuk memiliki kemampuan mengembangkan model pembelajaran yang efektif terutama pada mata pelajaran fisika.

Berdasarkan penjelasan di atas, peneliti mencoba menerapkan salah satu pembelajaran yang kiranya dapat mengatasi permasalahan yang telah disebutkan sebelumnya. Pembelajaran tersebut adalah pembelajaran Konstruktivisme dengan siklus belajar Karplus. Model pembelajaran ini membiasakan siswa 


\section{Jurnal Pendidikan Fisika Tadulako (JPFT)}

Vol. 1 No. 2

ISSN 23383240

untuk terlebih dahulu mengeksplorasi materi pembelajarn secara bebas sebelum materi tersebut dijelaskan oleh guru.

Berdasarkan penelitian sebelumnya, model pembelajaran dengan siklus belajar pernah diterapkan oleh Dyah Titin Kurniatin dan diperoleh kesimpulan bahwa keaktifan siswa meningkat serta hasil belajar yang dicapai pun lebih baik setelah diterapkan model Learning Cycle 5E di SMA Negeri 6 Malang. Ref.[1]

Begitu pula dengan data penelitian yang diperoleh dari Jurnal Pendidikan Inovatif Vol. 3, Nomor 1, September 2007, dengan judul penelitian yaitu Penerapan Pendekatan Konstruktivisme pada Pembelajaran Theorema Phytagoras di Kelas 8 SMP Nasional KPS Balikpapan diperoleh hasil bahwa pembelajaran Teorema Phytagoras dengan menggunakan pendekatan Konstruktivisme dinyatakan efektif. Ref. [2]

Berpedoman dari penelitian diatas, maka peneliti bermaksud untuk melakukan penelitian dengan menerapkan pembelajaran Konstruktivisme yang dipadukan dengan siklus belajar seperti yang digunakan pada penelitian tersebut diatas. Namun yang membedakannya, pada penelitian ini peneliti tidak menggunakan siklus belajar $5 \mathrm{E}$, melainkan menggunakan siklus belajar $3 \mathrm{E}$, dengan pertimbangan objek penelitian ini adalah siswa SMP yang baru duduk dikelas VII yang memiliki kemampuan menganalisis seperti siswa SMA.

\section{METODOLOGI PENELITIAN}

Penelitian ini merupakan penelitian tindakan kelas (PTK) yang dilakukan dalam dua siklus. Masing-masing siklus melalui tahap perencanaan, tindakan, observasi, dan refleksi. Tahapan penelitian ini diadopsi dari alur PTK model Kurt Lewin yang dikembangkan oleh Kemmis dan Mc.Taggart.

Subyek penelitian ini adalah seluruh siswa kelas VIIb 3 SMP Negeri 14 Palu yang terdaftar pada semester genap tahun ajaran 2011/2012 yang berjumlah 34 orang siswa yang terdiri dari 14 orang siswa laki-laki dan 20 orang siswa perempuan, metode pengumpulan data pada penelitian ini, meliputi beberapa cara yaitu, observasi menggunakan lembar observasi dan tes hasil belajar. Faktor-faktor yang diteliti dalam penelitian ini adalah aktivitas guru, aktivitas siswa, efektifitas individu dan kinerja kelompok, serta hasil belajar siswa. Analisa data terbagi menjadi dua kelompok yaitu analisa data kuantitatif dan data kualitatif.
Hipotesis tindakan pada penelitian ini adalah melalui penerapan pembelajaran Konstruktivisme dengan siklus belajar Karplus dapat meningkatkan hasil belajar fisika siswa kelas VIIb 3 SMP Negeri 14 Palu.

\section{HASIL DAN PEMBAHASAN}

Pelaksanaan pembelajarn fisika dengan penerapan pembelajaran Konstruktivisme dengan siklus belajar Karplus pada penelitian ini dijelaskan sebagai berikut.

Pelaksanaan pembelajaran pada siklus I dilakukan dengan menggunakan metode diskusi kelompok, presentasi dan tanya jawab. Pelaksanaan pembelajaran juga ditunjang dengan Skenario Pembelajaran, RPP, Lembar Observasi Aktivitas Guru, Lembar Observasi Siswa, Lembar Penilaian Afektifitas Siswa dan Lembar Penilaian Psikomotor yang telah disesuaikan. Sebelum memulai proses pembelajaran, siswa diberi kesempatan terlebih dahulu mengeksplorasi materi secara bebas untuk menemukan konsep-konsep yang berkaitan dengan topik materi yang akan dibahas pada saat itu. Setelah guru menjelaskan materi, kemudian membagi siswa dalam 6 kelompok. Selanjutnya, siswa melakukan kegiatan diskusi kelompok, mempresentasikan hasil diskusi kelompoknya di depan kelas dan menjawab pertanyaanpertanyaan pada Lembar Kerja Siswa yang telah disediakan. Setalah dua kali pertemuan, selanjutnya dilakukan evaluasi terhadap hasil belajar siswa.

Kekurangan dari pembelajaran pada siklus I adalah guru masih belum maksimal dalam menerangkan materi pada saat pembelajaran, siswa kurang menyimak penjelasan yang disampaikan oleh guru, siswa kurang maksimal dalam mempresentasikan hasil diskusi kelompoknya kepada kelompok lain, siswa kurang menyimak kesimpulan materi yang disampaikan oleh guru dan siswa juga masih belum mampu menyelesaikan soal-soal konsep dengan baik. Hasil belajar siswa pada siklus I sudah cukup baik, akan tetapi masih berada di bawah standar ketuntasan belajar klasikal dan sebagian besar siswa belum mampu memahami materi secara keseluruhan.

Pembelajaran siklus II dilaksanakan untuk memperbaiki kekurangan-kekurangan yang ada pada pembelajaran disiklus I. Pelaksanaan pembelajaran pada siklus II ternyata berjalan dengan baik sesuai dengan yang diharapkan. Siswa cenderung lebih aktif dan semangat mengikuti kegiatan pembelajaran. 
ISSN 23383240

Hasil belajar yang diperoleh siswa secara lengkap ditunjukkan oleh Tabel 1.

Tabel 1. HASIL BELAJAR SISWA SIKLUS I DAN SIKLUS II

\begin{tabular}{|c|l|c|c|}
\hline \multirow{2}{*}{ No. } & \multicolumn{1}{|c}{ Aspek Perolehan } & \multicolumn{2}{|c|}{ Hasil } \\
\cline { 3 - 4 } & Suklus I & Siklus II \\
\hline 2. & Skor maksimal & 15 & 15 \\
\hline 3. & $\begin{array}{l}\text { Skor tertinggi } \\
\text { memperoleh skor tertinggi }\end{array}$ & 2 orang & 6 orang \\
\hline 4. & Skor terendah & 8 & 9 \\
\hline 5. & $\begin{array}{l}\text { Banyak siswa yang } \\
\text { memperoleh skor terendah }\end{array}$ & 8 orang & 4 orang \\
\hline 6. & $\begin{array}{l}\text { Banyaknya siswa yang } \\
\text { tuntas }\end{array}$ & $\begin{array}{c}17 \\
\text { orang }\end{array}$ & $\begin{array}{c}28 \\
\text { orang }\end{array}$ \\
\hline 7. & $\begin{array}{l}\text { Banyaknya siswa yang tidak } \\
\text { tuntas }\end{array}$ & $\begin{array}{c}17 \\
\text { orang }\end{array}$ & 6 orang \\
\hline 8. & $\begin{array}{l}\text { Persentase daya serap } \\
\text { klasikal }\end{array}$ & $\begin{array}{c}71,18 \\
\%\end{array}$ & $\begin{array}{c}84,01 \\
\%\end{array}$ \\
\hline 9. & $\begin{array}{l}\text { Persentase ketuntasan } \\
\text { belajar klasikal }\end{array}$ & $\begin{array}{c}50,00 \\
\%\end{array}$ & $\begin{array}{c}82,35 \\
\%\end{array}$ \\
\hline
\end{tabular}

Berdasarkan analisa data tes hasil belajar yang dilakukan pada siklus I, diketahui bahwa hasil belajar fisika siswa kelas VIIb3 SMP Negeri 14 Palu sudah cukup baik, sebab hanya ada 8 siswa dari 34 siswa yang tidak memenuhi standar ketuntasan individu (75\%) sedangkan ketuntasan belajar klasikal (KBK) siswa mencapai $50,00 \%$ dan daya serap klasikal (DSK) siswa mencapai 71,18\%, namun hasil ini masih belum memenuhi standar ketuntasan belajar klasikal dan daya serap klasikal yang harus mencapai $80 \%$.

Dilihat dari hasil observasi aktivitas guru dan siswa diketahui bahwa ketidaktuntasan hasil belajar siswa ini disebabkan oleh beberapa faktor yaitu: guru masih kurang maksimal dalam menerangkan kembali semua materi yang disajikankan, dalam hal ini guru kurang maksimal meminta siswa untuk mencatat halhal penting yang dijelaskan dan kurang memberikan kesempatan kepada siswa untuk bertanya sehingga siswa kurang memahami materi-materi penting yang disampaikan oleh guru. Guru kurang memberikan kesempatan kepada kelompok lain untuk menanggapi hasil presentasi kelompok yang tampil sehingga siswa kurang maksimal dalam menjawab pertanyaan dari kelompok yang lain dan kurang memberikan kesempatan kepada kelompok lain untuk bertanya. Guru kurang maksimal menyimpulkan ide atau pendapat yang berkembang dari siswa, dalam hal ini kurang meminta siswa untuk memperhatikan simpulan yang diambil oleh guru sehingga siswa kurang mencatat hal yang penting dan mengoreksi pendapat mereka yang keliru serta memperbaikinya. Guru kurang maksimal membimbing siswa membuat kesimpulan dari materi yang telah dipelajari, dalam hal ini kurang mengarahkan siswa untuk membuat kesimpulan hasil diskusi sehingga siswa kurang mampu menyampaikan kesimpulan sesuai tujuan pembelajaran dan kurang menyimak kesimpulan akhir dari guru. Guru kurang maksimal mengkoordinasi siswa untuk bergabung dalam kelompok belajar yang telah dibentuk, dalam hal ini kurang meminta siswa untuk bekerjasama dengan teman kelompoknya. Hasil analisis aktivitas guru masih berada pada kategori cukup dan baik dan aktivitas siswa masih berada pada kategori kurang dan cukup untuk masing-masing pertemuan I dan II.

Dari hasil penilaian afektivitas siswa dan psikomotor siswa, diketahui bahwa masih ada beberapa siswa yang kurang berkonsebtrasi saat mengikuti pembelajaran. Selain itu, dalam kegiatan diskusi kelompok masih ada pula anggota kelompok yang kurang bertukar pikiran dalam menyelesaikan LKS. Siswa juga kurang aktif dalam kegiatan tanya jawab pada saat mempresentasikan hasil diskusinya. Dari hasil analisis afektivitas siswa dan kinerja kelompok diketahui bahwa aspek-aspek yang diamati masih berada pada kategori cukup dan baik.

Selanjutnya, dari hasil wawancara juga diketahui bahwa siswa masih sulit untuk menyelesaikan soal dalam bentuk konsep. Hal ini disebabkan karena guru kurang membimbing siswa dalam mengerjakan soalsoal konsep. Guru juga cenderung terburu-buru dalam menyampaikan materi sehingga siswa tidak paham secara merata.

Pada siklus II, peneliti berusaha meminimalisir beberapa penyebab yang mengakibatkan hasil belajar siswa pada siklus I belum memenuhi Indikator keberhasilan kuantitatif dan kualitatif. agar dapat meningkat dan memenuhi standar. Beberapa usaha yang dilakukan peneliti yaitu: peneliti lebih tenang dalam menyampaikan materi, serta menggunakan bahasa yang lebih mudah dipahami oleh siswa, peneliti menciptakan suasana keakraban terhadap siswa, selalu memotivasi dan menubuhkan rasa percaya diri siswa serta memberikan kesempatan bertanya lebih banyak dari pertemuan sebelumnya, peneliti berusaha mengkoordinir setiap siswa sehingga bisa mengerjakan atau menjawab soal-soal terutama soal konsep.

Berdasarkan analisis tes hasil belajar siklus II, diketahui bahwa hasil belajar siswa sudah 
ISSN 23383240

memenuhi indikator keberhasilan kuantitatif dengan ketuntasan belajar klasikal (KBK) siswa mencapai $82,35 \%$ dan daya serap klasikal (DSK) siswa mencapai $84,51 \%$ serta hanya ada 6 siswa yang belum memenuhi standar ketuntasan individu. Dari hasil analisis kualitatif, diketahui bahwa peran siswa yang sesuai dengan skenario pembelajaran dalam kegiatan belajar mengajar telah terarah dengan baik. Hal ini dapat dilihat dari hasil analisis lembar observasi aktivitas guru dan siswa yang meningkat yaitu pada kategori baik dan sangat baik. Selain itu, penilaian afektivitas dan psikomotor siswa juga mengalami peningkatan serta proses pembelajaran yang tidak didominasi hanya oleh siswa yang pintar saja. Dari hasil wawancara juga dapat diketahui bahwasiswa sudah mampu menyelesaikan soal soal konsep maupun perhitungan. siswa sudah mampu menyelesaikan soal-soal konsep maupun perhitungan.

Hasil belajar yang diperoleh pada siklus II meningkat dan lebih baik dari siklus I, hal ini dikarenakan faktor-faktor penyebab belum berhasilnya pembelajarn pada siklus I dapat diminimalisir. Peningkatan hasil belajar siswa dari siklus I ke siklus II dapat dilihat pada Gbr 1.

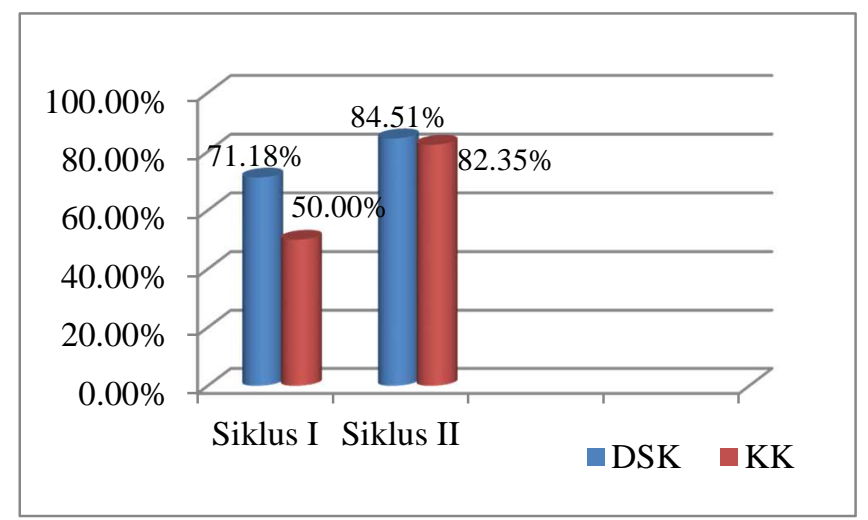

Gbr. 1. Grafik Hasil Belajar Siswa Pada Siklus I dan II

Berdasarkan Gbr.1. dapat dilihat bahwa peningkatan daya serap klasikal (DSK) dan ketuntasan belajar klasikal (KK) dari siklus I ke siklus II sebesar $13,33 \%$ dan $32,35 \%$. Berdasarkan uraian di atas, dapat disimpulkan bahwa penerapan pembelajaran konstruktivisme dengan siklus belajar Karplus dapat meningkatkan hasil belajar fisika siswa kelas VIIb3 SMP Negeri 14 Palu.

Kesimpulan ini juga didukung oleh penelitian sebelumnya yang dilakukan oleh Vitri Suka (2008) di SMP Bala Keselamatan Palu dengan hasil penelitiannya menunjukkan bahwa dengan menerapkan model siklus belajar tipe hipotesis deduktif dapat meningkatkan hasil belajar fisika siswa kelas VII SMP Bala Keselamatan Palu. Ref [3]

Penelitian lainnya yang juga menggunakan pembelajaran konstruktivisme adalah penelitian yang dilakukan oleh Rahmah Yuliana Aman (2007) dengan memadukannya melalui model Children Learning In Science (CLIS). Ref. [4]

\section{KESIMPULAN}

Berdasarkan hasil analisa data dan pembahasan pada penelitian ini, maka dapat disimpulkan bahwa penerapan pembelajaran konstruktivisme dengan siklus belajar Karplus dapat meningkatkan hasil belajar fisika siswa kelas VIIb 3 SMP Negeri 14 Palu. Hal ini dapat dilihat pada peningkatan hasil belajar dari siklus I ke siklus II. Untuk hasil belajar siswa siklus I diperoleh nilai ketuntasan belajar klasikal sebesar $50,00 \%$ dan daya serap klasikal $71,18 \%$. Sedangkan pada siklus II diperoleh nilai ketuntasan belajar klasikal sebesar $82,35 \%$ dan daya serap klasikal $84,51 \%$ yang artinya sudah memenuhi standar ketuntasan klasikal siswa. Peningkatan DSK dan KK dari siklus I ke siklus II masing-masing sebesar $13,33 \%$ dan $32,33 \%$. Untuk hasil observasi aktivitas guru dan siswa pada siklus I berada pada kategori cukup dan kurang, sedangkan pada siklus II berada pada kategori baik dan sangat baik.

\section{DAFTAR PUSTAKA}

[1] Kurniatin, Dyah Titin. 2010. Penerapan Metode Belajar Lerning Cycle-5E pada Mata Pelajaran Akutansi Terhadap Siswa Kelas XII IPS 1 untuk Meningkatkan Aktivitas dan Hasil Belajar di SMA Negeri 6 Malang. Skripsi dipublkasikan. Malang: Univerasitas Negeri Malang.

[2] Lasati, Dwi. 2006. Penerapan Pendekatan Konstruktivisme pada Pembelajaran Theorema Phytagoras di Kelas 8 SMP Nasional KPS Balikpapan. Balikpapan: Jurnal Pendidikan Inovatif Vol. 3

[3] Suka, Vitri. 2008. Penerapan Model Siklus Belajar Tipe Hipotesis Deduktif untuk Meningkatkan Hasil Belajar Fisika Siswa Kelas VII SMP Bala Keselamatan Palu. Skripsi tidak dipublikasikan. Palu: FKIP UNTAD.

[4] Aman, Rahmah Yuliana. 2007. Peningkatan Hasil Belajar Fisika Siswa Kelas VII SMP Negeri 4 Palu dengan Menggunakan Pembelajaran konstruktivisme Model Children Learning in Science (CLIS). Skripsi tidak dipublikasikan. Palu: FKIP UNTAD.

[5] Tim Penyusun. 2005. Pedoman Penyusunan dan Penilaian Karya Ilmiah. Palu: FKIP UNTAD. 